\title{
Renewable Energy for Rural Development in Bangladesh
}

\author{
Nashiyat Fyza ${ }^{1, *}$, M. A. Rashid Sarkar ${ }^{1, * *}$ \\ ${ }^{I}$ Department of Mechanical Engineering, Bangladesh University of Engineering and Technology, Dhaka 1000, \\ Bangladesh \\ Corresponding E-mail: fyzanashiyat@gmail.com; rashid@me.buet.ac.bd
}

\begin{abstract}
:
Energy is the key component to the development of a society. The demand for energy is increasing day by day. Around 16 percent of the global population does not have access to electricity. Around $64.96 \%$ of the population of Bangladesh lives in the rural area. This large portion often suffers from substandard quality of electricity. But electricity production by conventional fossil fuel power plant gives rise to greenhouse gas emission including carbon dioxide, nitrogen oxides and sulfur dioxide. These gases cause global warming and climate change. This has a detrimental effect on every living thing on the planet. Such consequences put Bangladesh in a perilous position, as most of the land is less than $10 \mathrm{~m}$ above the sea-level. As lands become more prone to be inundated, this poses a threat to our agriculture, health, sanitation and causes scarcity of clean water. Initiatives must be taken to popularize low carbon climate resilient energy sectors for sustainable development. A brief study of different forms of renewable energy sources is dealt in this paper. In this study, the present scenario and future prospects of renewable energy in Bangladesh has been presented.
\end{abstract}

Keywords: Energy, Solar Energy, Biogas Energy, Wind Energy, Biogas, Biomass.

\section{Introduction}

Energy is one of the basic ingredients required to alleviate poverty and ensure socio-economic development. Bangladesh has some reserves of commercial energy resources (e.g. natural gas and coal), due to economic and technical constraints; it is not being able to supply energy at the optimum level. Due to the increasing demand of energy in Bangladesh, dependency on imported fuel (oil and coal) is gradually increasing, and the rural population, which uses a fair amount of imported fuel (kerosene and diesel), is largely disadvantaged due to their low purchasing power. This situation calls for adaptation of sustainable energy strategies that permeate energy level of the economy and can provide rural dwellers with the basic services. Bangladesh has good potential for harnessing renewable energy sources such as solar, biomass, wind and mini-hydro. It has been experiencing a gradual shift towards exploring renewable energy resources as a means of driving force for rural development. Few public sectors and non-government organizations have started to take part to develop renewable energy technologies (RETs) projects. However, in Bangladesh efficient utilization of renewable energy resources is yet to assume commercial dimensions and hence rational policy dissemination on renewable energy usage is essential.

This paper elaborates different scopes of renewable energy technologies and their applications in the rural areas of Bangladesh through various literature review, case studies, examples and secondary data analysis. In the existing scenario renewable energy can play a more significant role in the energy sector of Bangladesh. This will require a proper and supportive government and nongovt. activities. Action plans to enhance adaptive research and commercialization of renewable energy technologies have been suggested.

\section{Energy Status \& Present Scenario}

Table 1: Total Installed Capacity [15]

\begin{tabular}{|l|l|l|}
\hline Fuel Type & Capacity (MW) & Total (\%) \\
\hline Coal & 524.00 & $3.09 \%$ \\
Gas & 10001.00 & $58.89 \%$ \\
HFO & 3597.00 & $21.18 \%$ \\
HSD & 1690.00 & $9.95 \%$ \\
Hydro & 230.00 & $1.35 \%$ \\
Imported & 660.00 & $3.89 \%$ \\
Others & 280.00 & $1.65 \%$ \\
\hline Total & 16982.00 & $100 \%$ \\
\hline
\end{tabular}

About $58.89 \%$ of the installed electricity generation capacity is based on natural gas. In the year 2018 (September), the natural gas production is $10001.00 \mathrm{MW}$ and the total installed electricity generation capacity is 16982 MW [15]. 
At present, $53 \%$ of the total electricity generation of Bangladesh is from the power plants under public sector and $47 \%$ of the net generation of the country is from private sector. In public sector, most of our power stations of the country have become very old and they are operating lower than their rated capacity with de-rated machineries. Met up the increasing demand of electricity is a great challenge for this country and as most of our power stations depend primarily on natural gas as fuel, because of the shortage of gas supply some power plants are unable to produce power of their rated generation capacity. Beside natural gas based power plants, other power plants are Hydro Electric Plant at Kaptai, the coal based plant at Barapukuria and several other power plants around the country. Renewable energy can be a great help to meet up the increasing demand. Moreover, the environmental drawbacks of renewable energy sources are minimum.

Table 2: Current power generation capacity of renewable energy [5]

\begin{tabular}{lll}
\hline \multicolumn{2}{l}{ Category } & Achievement \\
\hline 1. & SHS & $150 \mathrm{MW}$ \\
2. & Solar Irrigation & $1 \mathrm{MW}$ \\
& $\begin{array}{l}\text { Roof Top solar PV at Government, } \\
\text { 3. }\end{array}$ & $\begin{array}{l}\text { Power sector office buildings and at } \\
\text { newly constructed buildings }\end{array}$ \\
& $14 \mathrm{MW}$ \\
4. & Wind Energy & $2 \mathrm{MW}$ \\
5. & Biomass based electricity & $<1 \mathrm{MW}$ \\
6. & Biogas based electricity & $5 \mathrm{MW}$ \\
7. & Hydro power & $230 \mathrm{MW}$ \\
\hline & Total & $403 \mathrm{MW}$ \\
\hline
\end{tabular}

\section{Solar energy}

The sun is the largest object in our solar system and one of the larger stars in our galaxy. The energy that comes to the Earth is in 2 main forms, heat and light. The amount of energy from the Sun that reaches the Earth annually is $4 \times 10^{18}$ Joules. $4 \times 10^{18}$ Joules/ Year $\div 365$ Days/ Year $=$ $1 \times 10^{16}$ Joules/ Day. $1 \times 10^{16}$ Joules/ Day $\div 24$ Hours/ Day $=4 \times 10^{14}$ Joules/Hour [19]. The amount of energy consumed annually by the world's population is about $3 \mathrm{x}$ $10^{14}$ Joules. Every hour, enough sunlight energy reaches the Earth to meet the world's energy demand for a whole year.

Bangladesh is a subtropical country, $70 \%$ of year sunlight is dropped in Bangladesh. For this reason, we can use solar panels to produce electricity largely.
Bangladesh is located between $20^{\circ} 30^{\prime}$ and $26^{\circ} 45^{\prime}$ north latitude and the climate is tropical; the very location makes Bangladesh good recipient of solar energy [2]. Bangladesh has a total area of $1.49 \mathrm{E}+11 \mathrm{~m}^{2}$ and an average of $5 \mathrm{kWh} / \mathrm{m}^{2}$ solar radiation falls on this land over 300 days per annum [11]. Figure-1 [3] clearly shows that Bangladesh gets on average around $200-250 \mathrm{~W} / \mathrm{m}^{2}$ of sunlight.

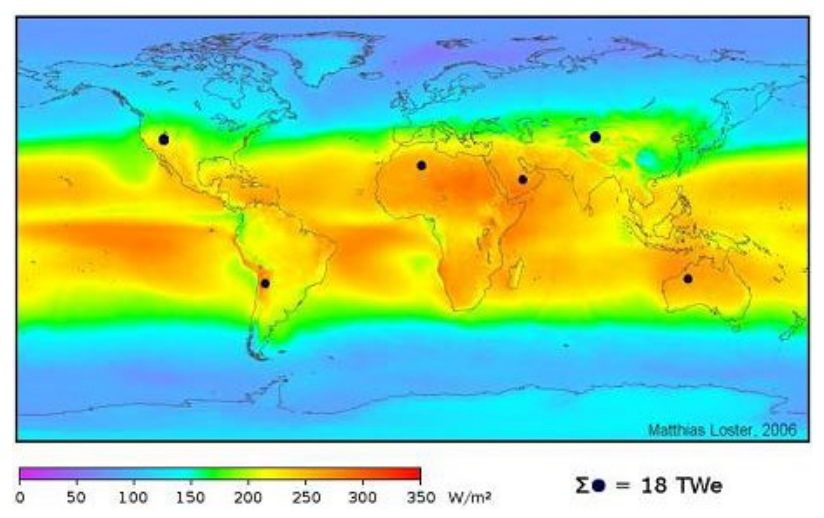

Figure 1: Average Insolation showing land area. Insolation for most people is from 150 to $300 \mathrm{~W} / \mathrm{m}^{2}$ or 3.5 to 7.0 $\mathrm{kWh} / \mathrm{m}^{2} / \mathrm{day}$. [3]

\subsection{Solar Photovoltaic}

Up to May 2017, about 4.12 million SHSs have been installed under the program in the remote areas where electrification through gird expansion is challenging and costly. Thus the program has ensured supply of solar electricity to 18 million people i.e. $12 \%$ of the country's total population who previously used kerosene lamps for lighting purpose. Scaling-up of solar PV systems assisted by the development partners are being implemented through Infrastructure Development Company Limited (IDCOL), Rural Electrification Board (REB), Local Government Engineering Department (LGED), Bangladesh Power Development Board (BPDB), NGOs and Private Organizations implementing solar energy program. There is a strong potential for solar energy within the country. Dissemination of solar home systems (SHSs) is being promoted up to $150 \mathrm{MW}$ by IDCOL private sector companies [11] and NGOs based on the direct-sale approach and provision of refinancing funds for micro-financing of SHSs to participating organizations (mostly NGOs) through IDCOL.

\subsection{Why Solar Energy in Bangladesh}

Solar Energy can be a great source for supplying increasing energy demand in Bangladesh. Using solar energy, simply, is a process which can provide energy from the sun. In this process, energy of the sun in the shape 
of photons reaches to earth and meets the world energy demand of the whole year with just one minute's solar radiation. Photovoltaic panel (PV panels-made of silicon) is the tool to harness solar energy. In light of the present demand for electricity; by 2020 the energy mix will be changed considerably from what it is today.

Solar energy is the most readily available, pollution free and free source of energy in our country and traditionally solar thermal energy has been utilized in different household and industrial activities in Bangladesh.

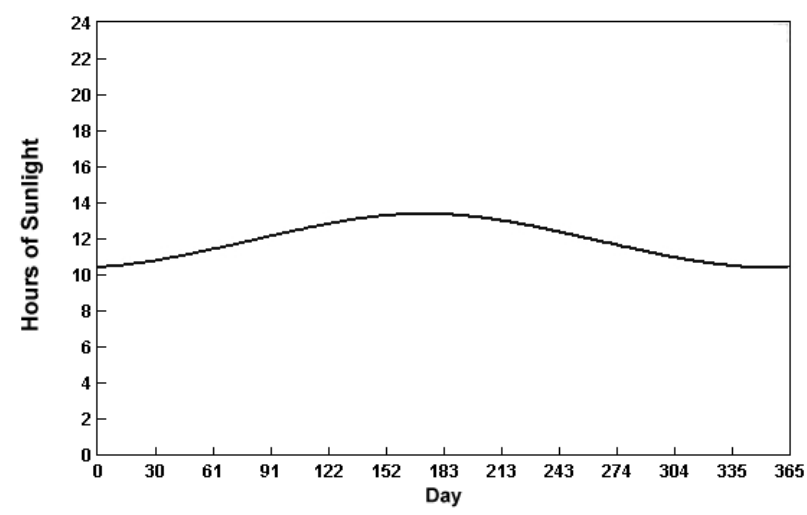

Figure 2: The number of hours of sunlight in Bangladesh

[3]

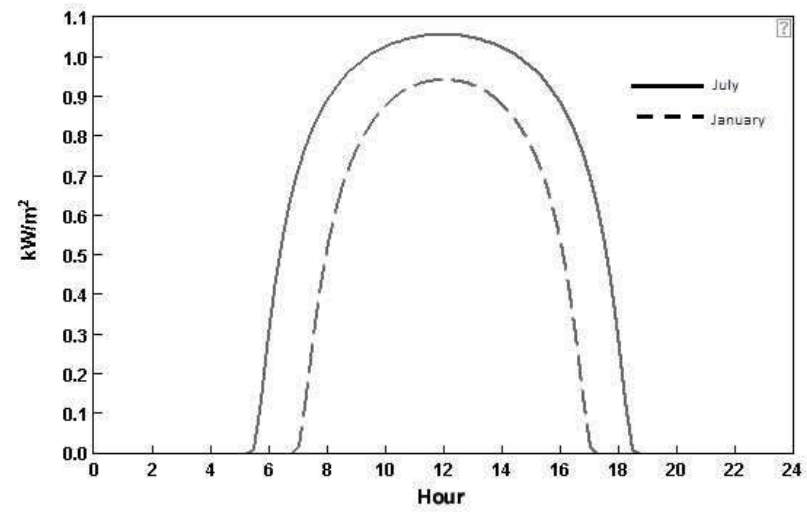

Figure 3: The highest and the lowest intensity of direct radiation in $\mathrm{W} / \mathrm{m}^{2}[3]$

Bangladesh is situated in an ideal location for solar energy utilization. Bangladesh is situated between 20.30- and 26.45-degrees north latitude and 88.04- and 92.44-degrees east which is an ideal location for solar energy utilization. At this position the number of hours of sunlight each day throughout a year is shown in the following graph in the Figure-2. The highest and the lowest intensity of direct radiation in $\mathrm{W} / \mathrm{m}^{2}$ are also shown in the Figure-3.

\subsection{Present Status of Solar Energy in Bangladesh}

Solar radiation varies from season to season in Bangladesh. So, we might not get the same solar energy all the time.

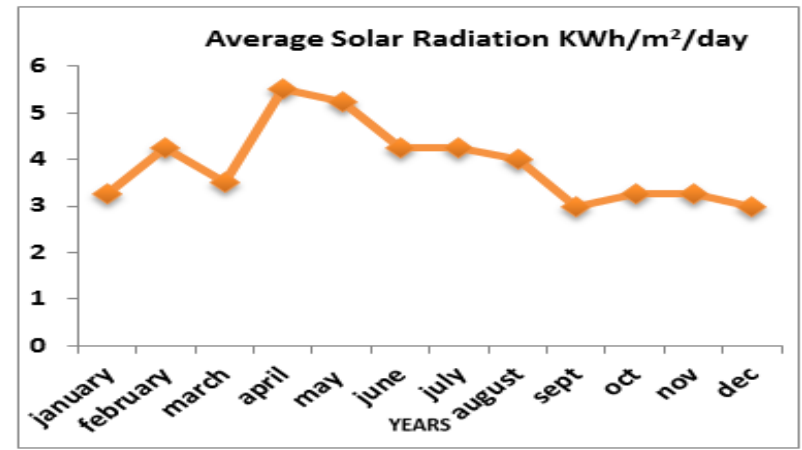

Figure 4: Monthly average solar radiation profile in Bangladesh [3]

Daily average solar radiation varies between 4-6.5 $\mathrm{KWh} / \mathrm{m}^{2}$. Maximum amount of radiation are available in the month of March-April and minimum in DecemberJanuary. According to IDCOL, the total capacity of solar energy based installations in Bangladesh appears to be 20.75 MW. The amount is significant considering the upward trend of the number of SHSs (Solar Home System) installations in the country.

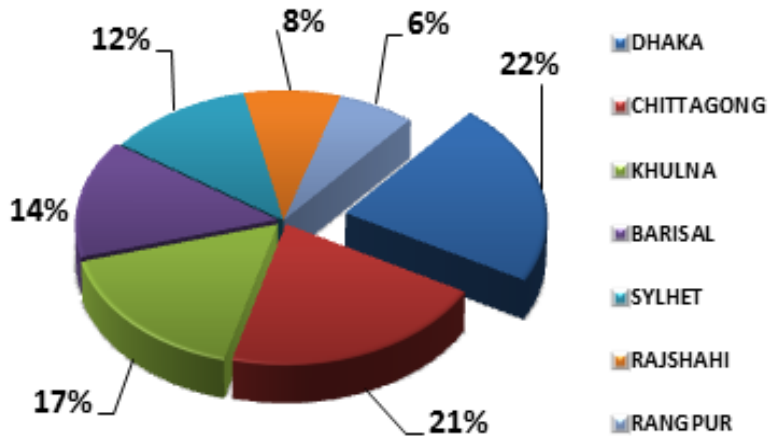

Figure 5: Distribution of the SHSs (Solar Home System) in seven divisions in Bangladesh [2]

The Figure 5 shows the approximate division wise SHSs installation. The figure illuminates that the distribution of the SHSs is highest in the Dhaka district whereas lowest in the newly formed district Rangpur. So, from the above figure and discussion we can say that there is a good prospect for solar thermal and photovoltaic application in Bangladesh. Solar Home System installation is increasing day by day shown in figure 6 , by the year 2017 it increased up to 4.12 million.

The Government of Bangladesh signed a \$78.4 million additional financing to further scale-up support for the successful solar home systems (SHS) program of Bangladesh. IDCOL will provide assistance as the implementation agency. The project will help install an 
additional 480,000 solar home systems that has emerged as a viable electrification option for areas without grid access to electricity.

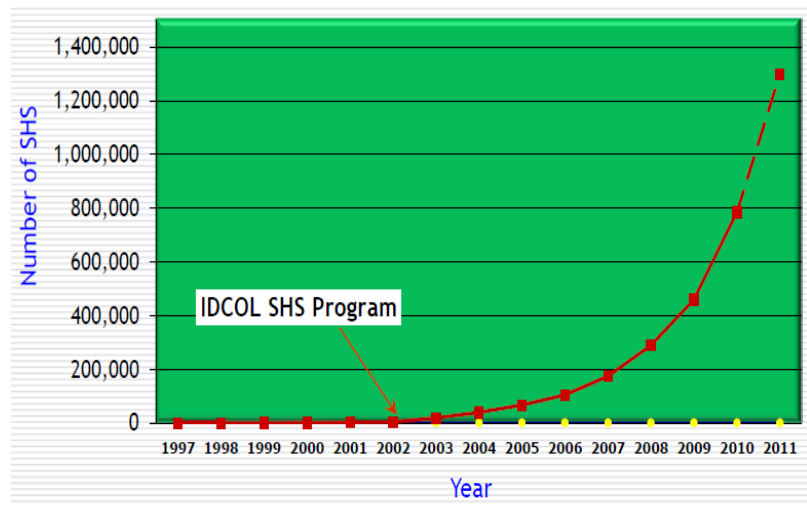

Figure 6: SHS installation [12]

\subsection{Solar Powered Refrigerator}

Solar powered refrigerators or solar refrigerators are widely used in the remote area of Bangladesh, where electricity is not available, for the preservation of vaccine and other lifesaving medicines. More than 200 clinics at the coastal area of Bangladesh are using solar powered refrigerators.

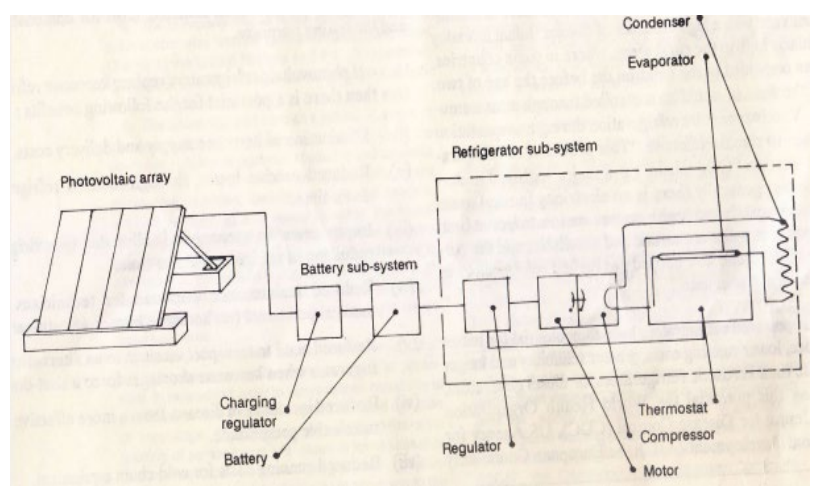

Figure 7: Schematic diagram of a solar powered refrigerator $[28]$.

\subsection{Solar Mini-grid}

Remote and dispersed areas are currently adopting offgrid electrification as a viable alternative to the national grid service. Solar Home Systems (SHS), established as a complementary solution to grid electrification, has proven it to be the most viable off-grid electrification today. Prokaushali Sangsad Limited (PSL) was engaged in providing the original concept leading up to the final SHS program design. Currently Bangladesh deploys over 70,000 SHS per month, with over 2.7 million in total, under the national solar home program executed by Infrastructure Development Company Limited (IDCOL) [27]. This is one of the most successful off-grid SHS programs, with the highest installation rate in the world today. Similar to SHS, solar mini-grid can also offer reliable service for rural off-grid areas in Bangladesh. With the initiative and technical support of PSL, private utility company Purobi Green Energy Limited (PGEL) has invested in the nation's first commercial solar mini-grid in the coastal island of Sandwip in Bangladesh, with financing from IDCOL.

\subsection{Implemented Solar Energy Projects}

Under the Hill Tracts Electrification Project BPDB has already implemented three solar projects in Juraichori Upazilla, Barkal Upazilla and Thanchi Upazilla of Rangamati District. Under 1st, 2nd and 3rd Phases, 1200 sets Solar Home Systems of $120 \mathrm{Wp}$ each, 30 sets Solar PV Street Light Systems of $75 \mathrm{Wp}$ each, 3 sets Solar PV Submersible Water Pumps of $1800 \mathrm{Wp}$ each, 6 steps Solar PV Vaccine Refrigerators for the Health Care Centres of $360 \mathrm{Wp}$ each and 2 sets $10 \mathrm{kWp}$ capacity Centralized Solar System for market electrification has been installed. So, a total of $173.81 \mathrm{kWp}$ Solar PV Systems have been installed in Juraichori, Barkal and Thanchiupazilla of Rangamati District under the Hill Tracts Electrification Project.

In the fiscal year 2008-09, BPDB implemented another two solar electrification projects in Angoorpota and DohogramChitmohol. Under this program, BPDB implemented 2 sets Solar Home System of 50Wp each, 2 sets Solar Home System of $80 \mathrm{Wp}$ each and 8 sets Solar Home System of $100 \mathrm{Wp}$ each. A total of $1.06 \mathrm{kWp}$ Solar PV Systems have been installed in Angoorpota and Dohogram Chitmohol.

BPDB implemented $20.16 \mathrm{kWp}$ Solar PV System and that was inaugurated by Prime Minister at the Office of the Prime Minister on December 2009 [11].

In line with the Government's Renewable Energy Policy, Power Division hosted 500 MW solar power development programs which is largest ever solar power development initiative in Bangladesh and so far among any LDC country. Under the initiative more than $500 \mathrm{MW}$ capacity commercial and social solar power projects will be commissioned. Out of $500 \mathrm{MW}$ solar $340 \mathrm{MW}$ will be implemented by Private sector and rest $160 \mathrm{MW}$ will be implemented in public sector. The categories of projects implement by the private sectors are:

- Grid tie solar park

- Solar Irrigation

- Solar Mini Grid

- Solar system at Industrial and residential Roof Top 
Social projects will be implemented by the different government agencies and bodies as their commitment towards society. Categories of projects implement as social responsibilities are:

- Solar Electrification at Rural Health Centre

- Solar Electrification at remote Educational Institutions

- Solar Electrification at Union E- Centers

- Solar Electrification at remote Railway Stations

- Installation of Solar System at Religious Establishment

- Solar PV system in Government offices

\subsection{Ongoing Projects}

$>650 \mathrm{KWp}$ (400 kW load) Solar Mini Grid Power Plant at remote Haor area of Sullahupazila in Sunamgonj district under Climate Change Trust Fund (CCTF) on turnkey basis.

$>8 \mathrm{MW}_{\mathrm{p}}$ Grid Connected Solar PV Power Plant at Kaptai Hydro Power Station at Rangamati on turnkey basis.

> $3 \mathrm{MW}_{\mathrm{p}}$ Grid Connected Solar PV Power Plant at Sharishabari, Jamalpur on IPP basis.

> $30 \mathrm{MW}_{\mathrm{p}}$ Solar Park Project adjacent to new Dhorola Bridge, Kurigram on IPP basis.

$>$ Solar Street Lighting Projects in seven (7) City Corporations of the country.

N.B Installation of Solar Roof Top Systems in all BPDB offices across the country is a continuous process. More than $223 \mathrm{~kW}_{\mathrm{p}}$ solar $\mathrm{PV}$ systems have already been installed and installations of about $407 \mathrm{~kW}_{\mathrm{p}}$ solar PV systems are under planning/implementing stages.

\section{$4 \quad$ Wind Energy}

Bangladesh has a $724 \mathrm{~km}$ long coast line and many small islands in the Bay of Bengal, where strong south-westerly trade wind and sea-breeze blow in the summer months and there is gentle north-easterly trade wind and land breeze in winter months [8]. Bangladesh is in the midst of a severe energy and power supply crisis; one of the worst in South Asia. However, the government is now looking to explore the potential of wind energy, particularly along the country's 700-kilometre-long coastline. Along the coastal area of Bangladesh, the annual average wind speed at $30 \mathrm{~m}$ height is more than $5 \mathrm{~m} / \mathrm{s}$ [18]. Wind speed in north-eastern parts in Bangladesh is above $4.5 \mathrm{~m} / \mathrm{s}$ while for the other parts of the country wind speed is around 3.5 $\mathrm{m} / \mathrm{s}[18,26]$.
Table 3: Wind speed of different sites at different height [18]

\begin{tabular}{|l|l|l|l|l|}
\hline Sl. & Location & Height & $\begin{array}{l}\text { Average Speed } \\
(\mathbf{m} / \mathbf{s})\end{array}$ & Remarks \\
\hline 1 & Cox's Bazar & $25 \mathrm{~m}$ & 3.792 & Good \\
\hline 2 & Charfession & $25 \mathrm{~m}$ & 4.433 & Better \\
\hline 3 & Chittagong & $25 \mathrm{~m}$ & 4.367 & Better \\
\hline 4 & Kuakata & $20 \mathrm{~m}$ & 3.135 & Good \\
\hline 5 & Kuakata & $30 \mathrm{~m}$ & 4.146 & Better \\
\hline 6 & Kutubdia & $20 \mathrm{~m}$ & 3.642 & Good \\
\hline 7 & Sitakunda & $20 \mathrm{~m}$ & 3.015 & Good \\
\hline 8 & Sitakunda & $30 \mathrm{~m}$ & 3.554 & Good \\
\hline
\end{tabular}

Recently, Bangladesh's first-ever generation of electricity from wind at a 900-kilowatt plant has ushered in new hopes for generation of power with minimum cost in the country. The power plant, located near the Muhuri Dam in south-eastern Feni district, have four separate wind turbines of $225 \mathrm{~kW}$ each. It is now ready to generate electricity from wind and supply to the Muhuri Irrigation Project and the national grid, according to The Bangladesh power development board. Beside several small wind generators have been installed by BRAC (11 small wind turbines in various coastal sites) and Grameen Shakti (two wind generators of $300 \mathrm{~W}$ and $1 \mathrm{KW}$ at its Chakoria Shrimp Farm). Grameen Shakti has recently installed 4 small wind generators $(3 \mathrm{xl} .5 \mathrm{KW}+\mathrm{ONE} 10 \mathrm{KW})$ in Barguna district. Grameen Shakti has already started providing electricity to fish and prawn farms in Cox's Bazaar, an important fishing port. The Bangladesh Power Development Board has estimated that wind energy can contribute to $10 \%$ of the energy needs of the country. The Board has also calculated the cost to generate one kilowatt hour of power $(\mathrm{kWh})$ from wind energy to be about half the cost of generating an equivalent unit of power from solar energy. The expansion of the potential of wind energy will be crucial in order for Bangladesh to achieve its national vision of providing electricity to all of its population by 2020. However, in order for targeted poor communities to enjoy the benefits of access to electricity, there may be a need for setting up of vocational training programs for rural and urban poor micro-entrepreneurs.

Wind Energy has also made some inroads but its potential is mainly in coastal areas, and offshore islands with strong wind regimes. These coastal settings afford good opportunities for wind-powered pumping and electricity generation. Presently there are $2 \mathrm{MW}$ of installed wind turbines at Feni and Kutubdia. 


\subsection{Implemented Wind Energy Projects}

Bangladesh is situated between $20^{0} 30^{\prime}-26^{0} 45^{\prime}$ North Latitude and $88^{\circ} 04^{\prime}-92^{\circ} 44^{\prime}$ East Longitude. The country has a $724 \mathrm{~km}$ long coast line and many small islands in the Bay of Bengal, where strong south-westerly trade wind and sea-breeze blow in the summer months and there is gentle north-easterly trade wind and land breeze in winter months [18].

The potential of wind energy is limited to coastal areas, off-shore islands, rivers sides and other inland open areas with strong wind regime. In order to generate electricity from Wind Energy, BPDB installed 4x225 KW $=900 \mathrm{KW}$ capacity grids connected Wind Plant at Muhuri Dam area of Sonagazi in Feni.

Another project of $1000 \mathrm{KW}$ Wind Battery Hybrid Power Plant at Kutubdia Island was completed in 2008 which consists of 50 Wind Turbines of $20 \mathrm{~kW}$ capacities each.

\subsection{Ongoing Projects}

$>$ Repairing work of the existing $900 \mathrm{~kW}$ grid connected Wind Power Project at Muhuri Dam of Sonagazi in Feni is going on.

$>$ Repair and operation \& maintenance of the existing Kutubdia 1000 kW Wind Battery Hybrid Power Project is underway

> Steps have been taken to install 15 MW Wind Power Plant across the coastal regions of Bangladesh after 1 year Wind Resources Assessment in Muhuri Dam Area of Feni, Mognamaghat of Cox'sbazar, and Parky Beach of Anwara in Chittagong, Kepupara of Borguna and Kuakata of Patuakhali. Wind Mapping is going on at Muhuri Dam area of Feni and at Mognamaghat of Cox'sbazar by RegenPowertech Ltd. of India.

> Installation of Wind Monitoring Stations at Inani Beach of Cox'sbazar, Parky Beach of Anwara, Sitakundu of Chittagong and at Chandpur under USAID TA project is underway

\section{Micro/Mini Hydro Projects}

Micro-hydro and mini-hydro have limited potential in Bangladesh, with the exception of Chittagong and the Chittagong Hill tracts. Hydropower assessments have identified some possible sites from $10 \mathrm{~kW}$ to $5 \mathrm{MW}$ but no appreciable capacity has yet been installed. There is one hydro power plant at Kaptai established in the 1960s with present installed capacity of $230 \mathrm{MW}$. Today hydropower generates about 17 percent of world electricity supplies.
Like biomass, hydropower is an established renewable energy technology that is widely used in many parts the world. The basic technology is simple: falling water flows through pipes, called penstocks, and then turns turbine blades to spin a generator and produce electricity (Figure 7). When excess power is available from the grid, some hydropower stations pump water up to storage reservoirs and hold it in reserve, then release it to generate power when demand rises.

\subsection{Implemented Hydro Projects}

Hydro-power is defined as power that is obtained from the force of moving water. It has been used for centuries as an energy source, with implementation ranging from irrigation, or the operation of various equipment such as water wheels or watermills. The modern usage of hydropower is mainly to generate electricity in hydro-electric power stations, providing around $20 \%$ of the world's electricity. Micro Hydro Power Plants can be installed in the north-eastern hilly regions and in the existing irrigation canal system with sufficient head.

Kaptai Dam is on the Karnaphuli River at Kaptai, 65 kilometers (40 mi) upstream from Chittagong in Rangamati District, Bangladesh. It is an earth-fill embankment dam with a reservoir (known as Kaptai Lake) water storage capacity of $6,477,000,000 \mathrm{~m}^{3}$ $(5,250,989 \mathrm{acre} \cdot \mathrm{ft})$. The primary purpose of the dam and reservoir was to generate hydroelectric power. Construction of the dam was completed in 1962. The generators in the 230 MW Karnafuli Hydroelectric Power Stations were commissioned between 1962 and 1988 $[3,6]$. It is the only hydroelectric power station in Bangladesh [4].

Currently there is a Micro Hydro Power Plant with a 50$\mathrm{kW}$ generator at Barkal area of Rangamati district in 2005 implemented by the Bangladesh Power Development Board (BPDB). A larger hydroelectric plant was built in the Kaptai region using the Karnaphuli River during the 1960s, and was Bangladesh's only hydroelectric power plant for a long time. It is capable of producing a total of 230 MW of electricity.

\subsection{Ongoing Projects}

> 50-70 kW Mohamaya Irrigation-cum-Hydro Power Project at Mirersorai, Chittagong.

$>$ Rehabilitation of $50 \mathrm{~kW}$ Micro-Hydro Power Plant at BarkalUpazila of Rangamati district.

In spite of some negative aspects, hydropower is an attractive alternative to fossil fuels for many countries 
with good resources. In addition to their low pollutant emissions, hydropower plants provide dispatch able power: their output can be raised or lowered quickly to meet fluctuating levels of demand. Other renewable sources, such as wind and solar energy, produce energy intermittently when the wind blows or the sun shines, so they are not as responsive to daily market conditions.

Table 4: District wise Energy Potential [2]

\begin{tabular}{|c|c|c|}
\hline District & River/Chara/Stream & $\begin{array}{l}\text { Potential of } \\
\text { Electrical } \\
\text { energy in } \mathrm{kW}\end{array}$ \\
\hline \multirow{6}{*}{$\begin{array}{l}\text { Chitta- } \\
\text { gong }\end{array}$} & Foy's lake & 4 \\
\hline & Choto Kunira & 15 \\
\hline & Hinguli Chara & 12 \\
\hline & Sealock & 81 \\
\hline & Lungi chara & 10 \\
\hline & Budia chara & 10 \\
\hline \multirow{3}{*}{ Sylhet } & Nikhari Chara & 26 \\
\hline & Madhab chara $1500 \mathrm{ft}$, from fall & 78 \\
\hline & Rangapani gung & 616 \\
\hline \multirow{2}{*}{ Jamalpur } & $\begin{array}{l}\text { Bhugi-kongsa at } 2 \text { miles U/S of } \\
\text { Nalita-bari P. S }\end{array}$ & $\begin{array}{l}69 \mathrm{~kW} \text { for } 10 \\
\text { months, } 48 \mathrm{KW} \\
\text { for } 2 \text { months }\end{array}$ \\
\hline & $\begin{array}{l}\text { Marisi at duka-bed near } \\
\text { jhinaigati Thana head quarter }\end{array}$ & $\begin{array}{l}35 \mathrm{~kW} \text { for } 10 \\
\text { months } 20 \mathrm{~kW} \\
\text { for } 2 \text { months }\end{array}$ \\
\hline \multirow{6}{*}{ Dinajpur } & Dahuk at Burabari & 24 \\
\hline & $\begin{array}{l}\text { Chawai at U/S. of Chawai L.L. } \\
\text { P }\end{array}$ & 32 \\
\hline & Talam at U/S. of Talam L.L. P & 24 \\
\hline & Pathraj at Fulbari & 32 \\
\hline & Tangon at D/S of Nargun L.L. P & 48 \\
\hline & Punarbhaba at Singraban & 11 \\
\hline \multirow{2}{*}{ Rangpur } & Buri Khora Chikli at Nizbari & 32 \\
\hline & Fulkumar at Rai-ganj Bazar. & 48 \\
\hline
\end{tabular}

\section{Biogas Projects}

Biogas mainly from animal and municipal wastes may be one of the promising renewable energy resources for Bangladesh. Presently there are tens of thousands of households and village-level biogas plants in place throughout the country. It is a potential source to harness basic biogas technology for cooking, and rural and perurban electrification to provide electricity during periods of power shortfalls.
An agriculture-based country like Bangladesh has huge potentials for utilizing biogas technologies. According to IFRD- there is potential of about four million biogas plants in our country. Biogas is a fuel gas, a mixture consisting of $65 \%$ methane $\left(\mathrm{CH}_{4}\right)$ and of $35 \% \mathrm{CO}_{2}$. In Bangladesh, people in rural areas are making use of this cost effective solution to energy needs in their kitchens and fields. Bangladesh produces about 1100 million cubic feet of natural gas daily and imports about three million tons of crude oil and petroleum product per year [24]. These are referred to as commercial energy and provide for 35 per cent of the total energy consumed in the country. It is the biomass energy source that is available to the latter and it consists of fuel wood, leaves, agricultural residues, cow dung and other organic wastes. These are referred to as non-commercial energy and actually provide for the remaining 65 percent of the total energy consumed in the country. About 80 percent of the total population of the country or about 100 million people live in rural area. The non-commercial biomass energy sources (fuel wood, cow dung, agricultural waste etc.), these people traditionally uses are inefficient and poorly managed. It is said that the country would require about 13.6 Tcf of gas up to 2020, about $26.7 \mathrm{Tcf}$ up to 2030 , and about 62 Tcf up to 2050[24]. With natural gas as the single significant commercial energy resource available in the country, it appears that the present reserve of 11.6 Tcf will not run beyond 2020[21]. Bangladesh remains far behind the neighbouring countries in developing biogas as apparent from the fact that the number of biogas plant installed is about 30 lacks in India, 70 lacks in China, 70 thousand in Nepal and only about 8000 in Bangladesh [1].

\subsection{Prospects of Biogas in Bangladesh}

The number of cows and buffaloes in Bangladesh is about 28 million ( 2 core 80 lakh), from this cow and buffaloes $322 \times 10^{6} \mathrm{~kg}$ dung left daily ( $1 \mathrm{cow}$ left average $11.50 \mathrm{~kg}$ dung) from $1 \mathrm{~kg}$ dung 1.3 cubic feet ( 0.037 cubic meters) gas produce per day. Thus from the total amount of cow and buffalos dung per day $11.91 \times 10^{6} \mathrm{~m}$ gas which can be equated to $2.21 \times 10^{6}$ ton kerosene or to $4.42 \times 10^{6}$ tons coal according to the calorific value can be produced. Beside the main component of urban solid waste in Bangladesh are organic food wastes [3].

Besides working in partnership with IDCOL, some organizations have constructed domestic biogas plants with their own funds. These are Grameen Shakti (about 3,664 plants of their own), BRAC (about 3,664 plants of their own), and some other private organizations which promote biogas plants independently [20]. Moreover, since May 2011, IDCOL along with its partner 
organizations; has installed 18,713 biogas plants indifferent parts of Bangladesh.

\subsection{Implemented Biogas Projects}

Currently, Bangladesh receives $2 \mathrm{MW}$ power from biogas and biomass technologies. In terms of process, sustainability is perceived less as an ultimate outcome and more as a pathway to change [1]. Biogas plants produce excellent safe fertilizers for use on the farm to produces plants and vegetables. Biologically digested biomass becomes ecologically clear fertilizer that increases crops up to $40-50 \%$ [1]. Farm waste including slurry and sewage sludge to a gas that can fuel a gas generator. Previous study results showed that the range of methane potential for single substrates was between $114-215 \mathrm{~L} / \mathrm{Kg} \mathrm{VS}$, except for leaves \& straw, which showed much lower potential than the above range [24]. But volumetric methane potential of leaves \& straw was the highest followed by food waste among any other single substrates. These results indicated the most biodegradable nature of food waste, and the suitability of using leaves \& straw as a bedding material to increase the volumetric methane productivity. However, process instability with both of these substrates and high ammonia concentrations with chicken litter were also observed [24]. The outcome of the study indicated that the whole quantity of dung produced in the stable was not fed into the plant [22]. It showed that out of the theoretical available dung (calculated based upon the number of cattle and poultry) of 5370.9 kilograms (81.37 kg/household on an average), 4327.7 kilograms (81\%) was fed into the biogas digesters. However, the prescribed quantity of dung based upon the hydraulic retention time of 40-45 days for the Bangladesh context is $6362.5 \mathrm{~kg}$, which is $19 \%$ more than the available feeding and $47 \%$ more than the actual feeding presently practiced [22]. The result shows that each cubic meter $\left(\mathrm{m}^{3}\right)$ of biogas convert biogas to electricity, in a biogas powered electric generator, which produces $2 \mathrm{KWh}$ of useable electricity, the rest turns into heat which can also be used for heating applications. Biogas plants produce heat after cooling generator without any additional gas combustion. $2 \mathrm{KWh}$ is enough energy to power 180 nos of $10 \mathrm{~W}$ energy bulbs for 12 hours in a poultry farm. Biogas plants produce excellent safe fertilizers for use on the farm to produces plants and vegetables. Biologically digested biomass becomes ecologically clear fertilizer that increases crops up to $40-50 \%$ [15]. It will save lots of money for using fertilizer at crops fields in Bangladesh. Biogas plants can help in the fight against global warming by allowing to burn methane from organic waste of the poultry farm, instead of letting it escape into the atmosphere where it adds to the greenhouse effect.

Projects by Governmental Organizations

- Biogas Pilot Plant Project by IFRD (20,000 plants within 2004)

- Biogas Project by LGED (1,200 plants)

\section{$7 \quad$ Biomass projects}

Bangladesh has strong potential for biomass gasificationbased electricity. More common biomass resources available in the country are rice husk, crop residue, wood, jute stick, animal waste, municipal waste, sugarcane bagasse etc. This technology can be disseminated on a larger scale for electricity generation. Production of rice husk energy is steady over decade and day by day it is increasing in trend. In 1991, the production of rice husk energy was $76.35 \mathrm{PJ}$ and it increased to $106.1 \mathrm{PJ}$ in 2004 (Figure 8). The growth of rice the husk production is calculated as $2.57 \%$ which is higher than the overall growth of traditional fuel (1.73\%) [17]. Bangladesh is an agricultural country so biomass is available in huge amount. Cattle dung, agricultural residue, poultry dropping, water hyacinth, rice husk etc. used for biomass power generation are available in Bangladesh [5]. The figure 9 below indicates that the amount of rice production in Bangladesh has been increased in recent years and this amount of production has made us more optimistic in using the rice husk as a biomass fuel which his nevertheless a perfect source of renewable energy in the context of Bangladesh [24].

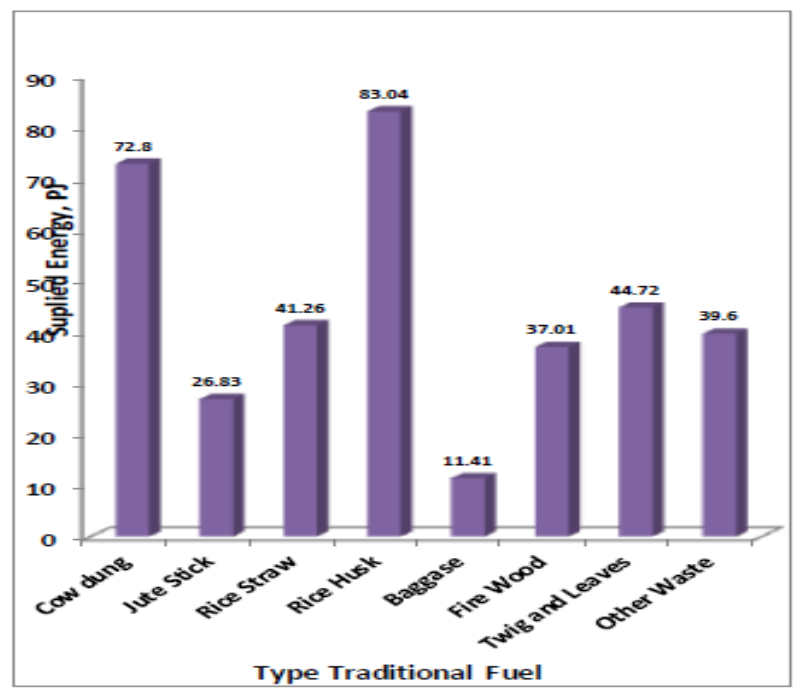

Figure 8: Estimated traditional energy supplied in the financial year 2003-2004 in Bangladesh (Source: BBS 2004) [24] 


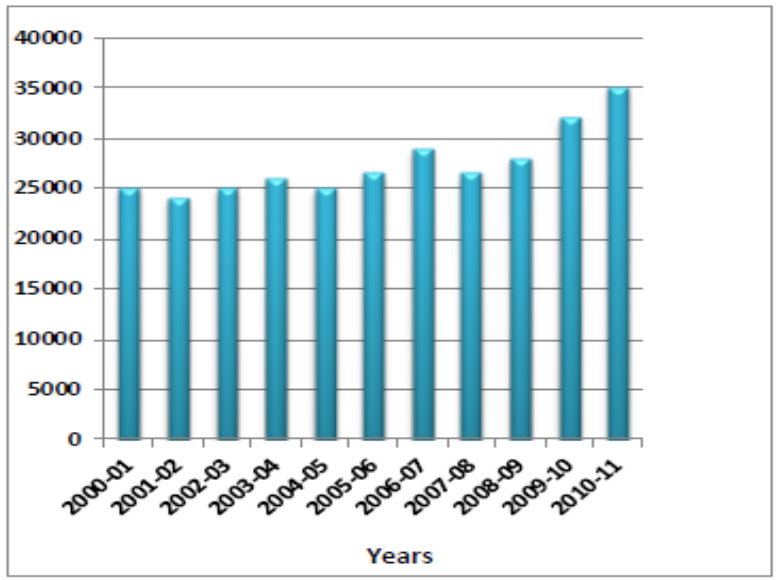

Figure 9: Rice production (Thousand Metric Ton) in Bangladesh in past eleven years [24]

\subsection{Implemented Biomass Projects}

Bangladesh's state-owned Infrastructure Development Company Ltd. (IDCOL) has sponsored a micro energy company called Dreams Power which, in collaboration with the World Bank and the Global Environmental Facility, inaugurated the countries first advanced, decentralized biomass power plant today. The facility, located in an un-electrified town named Kapashia (Gazipur district), is part of a rural electrification project that aims to reach about 700,000 citizens through renewable [19]. The green power plant, the first ever its kind in Bangladesh, is a $250 \mathrm{~kW}$ biomass gasification facility that generates renewable electricity from abundant agricultural residues such as rice husks. IDCOL provided concessionary loans and grants, sourced from IDA and the Global Environmental Facility (GEF), for a total project costly of 25 million taka $(€ 250,000)$ of which the World Bank provided $60 \%$. Being located in a non-electrified area, the plant is now supplying environmentally friendly grid quality power to about 500 households and commercial entities for the first time. A total of 220 consumers have been connected to the local grid, while another 2,300 applicants await connections.

\section{Challenges and Opportunities}

Our government has set a target of reaching all with electricity by 2020 . Momentum has been created for solar power which our rural people have accepted whole heartedly. Solar \& other renewable are in a position to play a very important role to complement government efforts to take electricity to all by 2020 . We are yet to reach the penetration rate of mobile phones or televisions which has reached more than half portion of the rural market. We are yet to reach cost effectiveness to reach all rural income groups especially the lower income group in large numbers.

\subsection{Challenges}

$>$ There are more than 30 organizations engaged in the rural renewable energy sector. Expect for a few, majority have a very small client base. Cutting edge business culture is yet to develop in this field because of the prevalence of NGO culture. There has been very little incentive for innovation or new product development because most of the organizations depend on guaranteed soft loans from IDCOL.

$>$ Present practice of vast rural network of branches and engineers translates in huge transaction cost and slow penetration rate. Lack of good communication especially during the rainy season constraints movements and increases transport cost.

$>$ Training and retaining efficient human resource at the field level is also difficult. Incentive is low compared to the hard work. It is difficult for organizations to increase incentives in order to keep their costs low.

$>$ There are many lacks in our country. Such as:

- There is lack of skilled engineers who can make cost effective and efficient SHS designs especially for productive applications.

- Lack of technological development

- Lack of resources - material \& manpower

- Lack of local industries to produce \& develop

- Lack of enough R\&D - in academia / industry

- Lack of governmental policies

- Lack of regional cooperation

- Lack of financial supports for new projects

- Lack of management on environmental hazards

$>$ Another major challenge is high battery prices and inability to source quality materials or accessories cost effectively.

$>$ Huge Tax and VAT are charged on import of all raw materials except solar panels. This increases the cost of local manufacturing of solar accessories which in turn increases the cost of Solar Home Systems.

$>$ The solar energy sector is facing problems with substandard solar panels and battery. There are complains that the battery quality is not up to mark to achieve satisfying performance. Insufficient warranty period of battery \& inverter is another problem.

\subsection{Opportunities and Recommendations}

Exponential demand has been created among rural people for solar power and renewable. This is mainly 
due to increased price of kerosene, diesel, and lack of grid connected power, decreased price of solar energy, and especially due to growing aspiration and economic diversification of the rural people.

> Technical progress has reduced cost, increased efficiency and diversified the application of solar energy.

$>$ We can use biogas technology not only generating cooking gas, but also for generating pure methane gas which can used for running vehicles, power pumps and other electronic equipment. This will facilitate rural development. We can use biogas technology in urban areas to convert wastes into electricity, gas and organic fertilizers.

> Again Biogas technology takes part in the global struggle against the greenhouse effect by reducing the release of $\mathrm{CO}_{2}$ from burning fossil fuels in two ways. First, biogas is a direct substitute for gas or coal for cooking, heating, electricity generation and lighting. Second, the reduction in the consumption of artificial fertilizer avoids carbon dioxide emissions that would otherwise come from the fertilizer producing industries.

$>$ To reduce technological problems, need cooperative supports from technologically-developed nations.

$>$ Need to learn from the experiences of countries like Japan to enhance the practical usage, implementation, investment, concern on pollution management, etc.

$>$ Need financial incentives.

$>$ Need new business models on micro-credits or others - based on regions.

$>$ Need industry support from international and local markets to develop various low-cost systems.

$>$ Need academic developments, more academic courses and reading materials - both in native language and in English to promote.

$>$ Need wider research opportunities so that smarter technologies and ideas on applications can be explored by students and academics.

$>$ Awareness and encouragements are necessary such as deploy environmental groups, media, etc.

$>$ Find more potential customers.

$>$ Need to build related industries and plan to produce solar cells, solar panels, and other key materials locally.

$>$ Government should support these projects so that it can bring revenue by exporting the products as well as enhance the chance to have local-made low-cost products for the citizens.

$>$ Need to arrange workshops, training programs or related issues, national and international conferences to share ideas and to establish networks - so that these can be monumental for the development on solar energy.

$>$ Need to teach and enforce industries to take special measures on health hazards on workers who are related to this industry.

$>$ Need to bring users, entrepreneurs, investors, NGOs, workers, academia, industry, etc. together to discuss on challenges and constraints they are facing in enhancing the usage of solar energy systems.

$>$ To overcome - need more understanding on various aspects and to know limitations and ways to mitigate.

\section{Closing}

The summary of this paper exhibits that, there is a considerable opportunity of Bangladesh to meet its future power demand and thus economic growth through renewable resources. Renewable energy sources discussed above can help Bangladesh produce more power. Time has come to look forward and work with these renewable energy fields to produce electricity rather than depending wholly on conventional method. With the help of these resources Bangladesh can generate electricity to meet the required internal demand in the future.

\section{References}

[1] Badrul, I. "Biogas energy in Bangladesh". "Bangladesh Gazette: Renewable Energy Policy of Bangladesh 2008", published in November 06, 2008. Website: http://lib.pmo.gov.bd/.pdf.

[2] Zaman M., Islam M. A., and Sarkar M. A. R. (2006). "Two Phase Heat Transfer in Solar Water Heater". National Seminar on Renewable Energy: Biomass/Bio Energy, Dhaka, 24th March, 2006.

[3] M A R Sarkar, Am Aziz Ul Huq Renewable Energy for Sustainable Development A paper presented 1t $3^{\text {rd }}$ Int Conference organized by IEB

[4] M. Ali, M.A.R. Sarkar, Z.M. Hasan, "Present Status of using Biogas Plant at Pabna District in Bangladesh", Int. J. Thermal \& Environmental Engineering, V-1, 2010.

[5] Bangladesh_Energy_Situation, Website: https://energypedia.info/wiki/.

[6] "Dam - Kaptai Dam". Retrieved 2007-02-01.

[7] Hossain, "Wind Energy in Bangladesh," Sustainable Development Networking Programme.

[8] “Infrastructure Development Company Ltd.", Website: http://www.idcol.org/ 
[9] http://www.tandfonline.com/doi/abs/10.1080/0790062022 0121756? journalCode $=$ cijw20\#preview

[10] Huque, S. and Mazumder, R. K. (2006). “A concentrator PV power system in water pumping". National Seminar on Renewable Energy: Biomass/Bio Energy, Dhaka, 24th March, 2006.

[11] IDCOL: Renewable Energy Projects, "EXPANDING RENEWABLE ENERGY IN BANGLADESH".

[12] IDCOL Renewable Energy Projects, Bangladesh, (2016, January).URL:http://www.idcol .org/energy Project.php.

[13] "Kaptai Dam Structure". Retrieved 2007.

[14] "Key Statistics"Bangladesh Power Development Board. Retrieved 2014-11-03 (introduction).

[15] http://www.bpdb.gov.bd/bpdb/index.php

[16] M. Ahiduzzaman. "Rice Husk Energy Technologies in Bangladesh," Agricultural Engineering International: the CIGRE journal.

[17] Md. Abdul Gofran, Md. Ashrafuzzaman, Md. Rahman 2009, "IDCOL Model Biogas Plant”.

[18] M.J. Khan, M.T. Iqbal, S. Mahboob, “A wind map of Bangladesh,” Renewable Energy (2004), Volume: 29, Issue: 5, Publisher: Elsevier, Pages: 643-660, ISSN: 09601481, DOI: 10.1016/j.renene.2003.10.002.

[19] M. Zunaid Baten, E.M.Amin, A. Sharin, R. Islam, S. A.Chowdhury, "Renewable Energy Scenario of Bangladesh: Physical Perspective," International Conference on the Developments in Renewable Energy Technology (ICDRT) 2009, Dhaka, Bangladesh

[20] Norman J Rosenberg, Steven J Smith, 2009, 'A sustainable biomass industry for the North American Great Plains', PACE.

[21] Prakash C 2005, 'Ghimire, Final Report on Technical Study of Biogas PlantsInstalled in Bangladesh'.

[22] Renewable Energy Prospects \& Trends in Bangladesh Presented by-Mazharul Islam. Bangladesh Power Development Board.

[23] Rice Production (Thousand Metric Tons) in Bangladesh. Available at: http://bangladesheconomy.wordpress.com/2011/12/11/350-cr-tonne-rice-production-target-fixed/.pdf.

[24] S.M. Ashekuzzaman 2010, 'Evaluation of biogas potential for rurally available biomass: a case study for the project areas in Bangladesh', Aalborg University June.

[25] T.V. Ramachandra, B.V. Shruti, "Wind energy potential mappings in Karnataka, India, using GIS," Energy Conversion and Management 46 (2005) 1561-1578, doi :10.1016/j.enconman.2004.07.009.

[26] World Journal of Social Sciences Vol. 2. No. 7. November 2012 Issue. Pp. 174 -181, Biogas Technology for a
Sustainable Energy: The Case of Poultry Farm in Bangladesh Rumana Rashid, Mohd. Hamdan Bin Ahmed, Md. Sayem Khan.

[27] Hasna J Khan and Asma Huque, "First Solar Minigrid in Bangladesh", Prokoushol Sangshad Limited, 25 May,2014.

[28] A Derrick and J M Durand, "Photovoltaic Refrigerators For Rural Health Care: Experiances and Conclusions", ISES, pp 20, 198 